УДК 821.163.41.09:398

https://doi.org/10.18485/godisnjak.2020.15.2

Зоја С. Карановић*

Универзитет у Новом Саду

Филозофски факултет
Оригинални научни рад

Примљен: 15. 09. 2020.

Прихваћен: 10. 11. 2020.

\title{
ЛАЈТЕ ГА, ПЦЕТА, ЛАЈТЕ ГА: \\ СМЕХОВНО И ЕРОТСКО У СРПСКИМ НАРОДНИМ ПЕСМАМА КОЈЕ СУ ПЕВАНЕ НА СЕДЕНЋУ - ИЗ ТЕРЕНСКЕ ЗБИРКЕ СА ТИМОКА
}

У спомен на наше домаћине на терену, на баба Живану и деда Перу Алексића

Предмет рада представља неколико записа српских народних песама које су извођене на седењкама које је ауторка, заједно са Весном Ђукић, забележила у селима око Белог Тимока, 1997. и 1998. године. И било да представљају јединствене записе или имају варијанте на ширем терену југоисточне Србије, или су (према постојећој документацији) певане на читавом српском демографском и духовном простору, ове песме представљају трагове живота усмене традиције у Срба и чудо су сећања њихових извођача. Оне сведоче жанровску и поетичку динамичност усмене песничке традиције, њену флексибилност и, посебно, неотуђивост од српске народне поезије и традиције у целини, која је овде утемељена у ритуалу, у његовој смеховној димензији, без обзира на то што се њихова обредност, која им је некада била упоришна тачка, понекад препознаје само у траговима.

Кључне речи: села око Белог Тимока, теренска бележења, српска усмена традиција, лирска народна песма, седенћа, седенћарске песме, обредна смеховност.

"zojanko@stcable.net 
Ауторка овог рада боравила је, заједно са Весном Ђукић, на терену у делу Тимочке Крајине, у селима око Белог Тимока ${ }^{1}$, у неколико наврата 1997. и 1998, кад је забележено преко 250 српских народних песама, које се у облику књиге припремају за штампу. Касније, 2014, 2015. и 2016, радила је на истом терену с групом колега и студената чије истраживање је организовала и предводила. ${ }^{2}$ Намера је тада била да се, поред осталог, провере већ сачињени записи и, евентуално, пронађу нове још увек живе песме. ${ }^{3}$ Показало се, међутим, да већина ранијих казивачица више није међу нама ${ }^{4}$, док се оне са којима су разговори у новије време вођени углавном више нису сећале песама. ${ }^{5}$

О седењкама на простору источне и југоисточне Србије сведоче записи који потичу с краја 19. века (в. Ризнић 1894: 96-99)', док је у време овог истраживања на терену живело само сећање на њих. Седењке/ђанке/ љке..., на ширем терену прела, или сијела ${ }^{7}$ су започињала од Госпођинских поста (Ризнић 1894: 96-99), у Тимоку на Преображење ${ }^{8}$ (Станојевић 1929а: $46-47)^{9}$, у основи онда кад се доврше пољопривредни радови, кад су амбари пуни и влада опште благостање. Према сведочењу наших казивачица:

${ }^{1}$ Теренска истраживања обављана су у селима: Боровац, Бучје, Валевац, Врбица, Витковац, Дебелица, Дреновац, Јаковац, Јелашница, Кожељ, Мариновац, Мали Извор, Ново Корито, Ошљане, Петруша, Потркање, Равна, Селачко, Трновац.

${ }^{2}$ На терену су тада биле професорке: Биљана Сикимић, Соња Петровић, Јасмина Јокић и Данијела Поповић Николић, као и студенти: Татјана Вујновић, Кристина Еивилер, Наташа Дракулић, Николина Тутуш и Даница Јовић. Њихови записи у овом раду нису коришћени.

${ }^{3}$ Напомињем да се рад на терену одвијао без икакве финансијске потпоре било које државне институције или невладине организације, као и без претходне припреме везане за сондирање терена и у вези с тим помоћи локалних власти. Рад је обављан методом случајног одабира саговорника. Разговори су у првом наврату снимани касетофоном, касније диктафоном, кад је било могуће. Разговори су иначе вођени уз пуну усмену сагласност казивача, на чему им захваљујемо.

${ }^{4}$ Нека почивају у миру.

${ }^{5}$ Свим нашим живим казивачицама топло захваљујемо. Такође захваљујем колегиницама и студентима на уложеном труду у оживљавању сећања казивача.

${ }^{6}$ Овај обичај познат је на српском и јужнословенском простору и имао је различите називе (в. Шорак 2013: 209). Као глагол „сијелити, ићи по сијелима”, помиње га Караџић у Рјечнику $(1818,1852)$. У Рјечнику, без ширег тумачења, такође доноси лексеме: посијело, прело, сијело.

${ }^{7}$ Вук Караџић је објавио неколико оваквих песама 1841 . године, за које је рекао да су то „пјесме које се пјевају на прелу” (бр. 240-244), док је прву међу њима публиковао још [1815] 1965: бр. 99. О изворима грађе види: Шорак 2013: 207-225.

${ }^{8}$ Које по народном веровању представља границу између лета и зиме, јер се тада, веровало се, преобрази и гора и вода - ово сам први пут чула у детињству од мајке. Види и: Недељковић 1990: 188; Петровић 1998: 367.

${ }^{9} \mathrm{У}$ различитим крајевима датуми су варирали, али се почетк седенће углавном везивао за велике свеце, којим се маркирају и промене у природи. 
Седенћа почне од Преображење. Праве се напоље, на крстопутине. На првој седенћи се запали ватра, обикаља се огањ с врежу и прескачу га момци и девојке. Само туј вечер не ради се у руке ништа. Напољу се праве целу јесен, док не'е ладно, пече се корење, праје се смеј, премењују се мушкарци у женско, женско у мушко, коло се играло, дудуци и гајде, била музика... ${ }^{10}$

(Љиљана Милосављевић, Ошљане).

Кад захладни, онда су седенће биле у кућама. По две девојчице иду по селу и скупљају гас за светло, за лампу, даје ко колико може.

(Мира и Зора Васиљевић, Селачко)

Ови искази потврђени су у етнографској литератури која се односи на локални терен и суседне области, као и слична ноћна окупљања каква су некада била прела на читавом српском демографском и културном простору. ${ }^{11}$

Седењке су, према информацијама у литератури и са терена, дакле, трајале током јесени, док не падне снег (у време мировања вегатације) $)^{12}$, временски се наслањајући на обреде летњег периода, односно на завршетак пољских радова. Одржаване су ноћу, на средини села, на раскрсницама, под записом, по двориштима (гранични хронотопи), у радне дане, никад пред празник (Ризнић 1894: 96-99), или уочи петка и петком (Станковић [1906] 1951: 59). На месту где се одржавала седенћа, палила се ватра и састајали се момци и девојке које су седенћу, заједно са старијим женама, и организовале. „Одржавају их жене, особито старије а највише „пророчице" којих је било врло много у Тимоку" (Станојевић 1929а: 42). ${ }^{13}$ Прво су долазиле девојке. Кад се оне искупе, једна девојка се свуче гола, узјаше „кросно” (вратило), а остале узму „сукала”. Она, на кросну јашући, обилази око огњишта, а остале сучу на сукалу. То се све чини да би се момци око њих скупљали. Како се, веле, сукало врти, тако да се око њих момци врте. Поред тога, прескачу ватру, чарају главње и говоре: „Кол’ко искре, тол'ко момци"! Ако која девојка не би долазила на седењку, говорило се да она не долази јер је нездрава, има „горопадну болест” - на тај начин приморавају је да дође (Станојевић 1929а: 46-47). Свуда, као и на

\footnotetext{
${ }^{10}$ О томе види шире и: Ћирић 1977: 186.

${ }^{11}$ Види податке о широј литератури: Шорак 2013: 207-225.

${ }^{12} \mathrm{O}$ флексибилности време-простора одржавања седењки на ширем српском и јужнословенском простору види: Шорак 2013: 209.

${ }^{13}$ Стеван Мачај пише о празновању у овом крају овако: „Осим славе и многих прописаних светковина наш народ празнује још гдекоје дане, за које црква не зна. Ови празници, које особито женскиње у прсте знају, стоје по свој прилици у свези са којекаквим природним појавама или другим неким догађајима, који су се кадгод у те дане збили и којих се спомен одржао у памети народа, због особитих последица, које су зар ти догађаји имали" (према: Станојевић 1929: 42).
} 
испитиваном терену, с којим су наши записи аналогни, то је дакле била и прилика за окупљања младих да се, између осталог, боље упознају и зближе: „Вачање и целивување” момака с девојкама било је на седењкама нормална појава и нико то није узимао за зло (в. Ћирић 1977: 186). Све то je, уосталом, претходило брачном везивању, што показује иницијацијску димензију седењке (окупљање и изолација младих). ${ }^{14}$

У збирци се налази осамнаест седенћарских песама или, како су их наше казивачице називале, „песме на седенћу”. По времену извођења, уз рад, ове песме блиске су посленичким - „свака седенћарка си донесе троношку и ручни рад, кудељу са вуном или игле 'плетиљће'” (Раденковић: https://www.monografija.rs/monografija/kulturna-bastina/pesme/). Док теку песме, шале, приче, игре, врачања, разбрајања, загонетања (Ризнић 1894: 135), „девојће не дангубе, преду вуну, клачишта (кучине), плету [...] припремају дарове за удају" (Раденковић: https://www.monografija. rs/monografija/kulturna-bastina/pesme. А по садржини седенћарске песме су блиске љубавним, уз то пригодне ${ }^{15}$ (Ризнић 1894: 116) - и шаљиве и озбиљне, обично песмице тренутне емоције и импровизације, које су се делимично или у целини уклапале у ширу традицијску матрицу, што показују теренски записи из Белог Тимока.

На седенћу се у Тимоку, и шире у југоисточној Србији припевало ${ }^{16}$, као и у сличним, на пример, за овцама или на свадби, конкретној именованој девојци и момку, на пример у песми бр. $9^{17}$, овако:

Старо сено развучено (име девојке)

Узни вилу, прибери га (име момка),

о чему је Слободанка Милојевић (Дебелица) рекла: „Припевала се, девојка момку, као да му се препоручује", провоцирајући га изазовом на рад, а заправо показујући своју наклоност и тражећи прилику да му се обрати и изрази симпатију.

Забележено је и неколико дистиха, такође насталих у резултату тренутне понесености (бр. 5 и бр. 6), али с базименим ликовима-јунацима

\footnotetext{
${ }^{14}$ O функцијама седењки у суседним областима види и: Шорак 2013: 210-211.

${ }^{15}$ То су припеви који се у литератури називају још и „посебне песме” (Ћирић 1977: 177), будући се односе на конкретног момка и девојку, као и песме које експлицитно помињу седењку.

${ }^{16}$ Припевке или припевушке, у Тимоку: „нарочита врста женских лирских песама, које су махом кратке, у њима се 'везују' већ напред 'момче и 'девојче'” (Станојевић 1929б: 24, 27). „Овога припевања има од пролећа, преко лета и јесени, при пољским или другим радовима. И ствар не остаје само на припевању, већ се ова врста 'гледања' преноси и на саборе, свадбе, благе дане, ора, кола) итд. - свуда где год се младеж сакупља (Станојевић 1929б: 27).

${ }^{17}$ Песме се наводе у поретку у којем се налазе у Прилогу уз овај рад.
} 
(о јунацима в. Самарџија 2010: 7-27), што их приближава старијем слоју традицијског певања, на пример:

Бела лампа, зелен гас,

Ајте, момии, сви код нас.

(Слободанка Милојевић, Валевац)

Или:

Иде гара, свитка му циигара,

Иде луче, залаја га куче.

(Вукосава Милетић, Бучје)

И, колико је ауторки рада познато, оне такође представљају јединствене записе, као и претходни стихови.

Комични ефектат у овим дистисима постиже се семантичком тензијом неспојиве садржине првог и другог стиха, који граматичким паралелизмима прво подижу напон, а онда га, семантичким антагонизмима, снижавају; затим, употребом речи које припадају урбаној култури (лампа, гас, цигара), те неочекиваним, за старији слој певања непознатим римама, удаљавају од матрице традицијског певања. А интензивирајући садржинску тензију скривају стварну емоцију, која се назире иза хињене бесмислености ругалице. Комични ефекти који се поменутим поступцима остварују повезују стихове веселошћу опште атмосфере седењке, која је утемељена у прастарим веровањима да смех јача животну снагу (Проп 1984: 146), и песму, као и седенћу, повезују с обредима за плодност.

Игре речима, с неочекиваним обртима и присуством урбане лексике, честа су појава у новијем слоју певања, такође у нешто развијенијим примерима седенћарских песама ове збирке. Једна од њих, у исказу девојке, садржином прати изразе пажње с момачке стране (бр. 7), што је на седењкама био и обичај ${ }^{18}$, у стиховима:

Синоћ ми је долазио Миле,

Донео ми три кутије фине.

У једну је пудер и помада,

А у другу шећер, чоколада,

А у трећу, девојчииа млада.

(Каравилка Радивојевић, Јелашница)

${ }^{18}$ За своју драгу „неко спреми и киту цвеће, мирис, сапун, огледалце” (Ризнић 1894: 98). 
Реквизити, односно дарови које Миле доноси девојци (кутија, пудер, помада, шећер, чоколада), припадају свету страном руралној култури ${ }^{19}$ и текст песме дистанцирају од ње. Песма, такође, упркос донекле очуваном десетерцу (као обележју старинског певања), не одолева заводљивости новотарије риме. Али будући да све то резултира својеврсном ситуацијом каламбура, у којем преплитање старог и њему непримереног новог резултира комичним ефектима, то и ове стихове враћа прастарим упориштима.

На седећну су извођене и песме које припадају старијем слоју певања, у неримованим десетерцима, мотивски везаним за поменути обичај ноћног окупљања ${ }^{20}$, какви су „непримерени” доласци старца на седенћу (бр. 1), с познатом уводном формулом ${ }^{21}$ : баба стари ${ }^{22}$, у којој баба настоји да спречи деду ${ }^{23}$, жељног девојака, да им се придружи, али у томе не успева, у стиховима:

\footnotetext{
${ }^{19}$ Момак је девојци некада даровао цвет, јабуку, огледалце, прстен итд.

${ }^{20} \mathrm{O}$ традиционалним и изведеним називима и типовима седењћарских песама види и: Шорак 2013: 213-214.

${ }^{21}$ Под појмом формуле подразумевају се устаљена и наслеђена средства изражавања, која се у науци именују и дефинишу разнолико, при чему ће се у овде као полазна дефиниција користити она која каже да је формула основно градивно језгро усмене песничке традиције, како то за епику каже Албет Лорд, односно представља (речи) и скупине речи које се редовно користе „под истим метричким условима да израз[е] дату основну идеју” (Рarry), док се под формулативним изразом означава „стих или полустих конструисан по обрасцу формула” (Lord 1990: 21) - иако неки елементи ове дефиниције, као на пример, „основна идеја”, нису до краја прецизирани; а будући да се формуле јављају и у прозним усменим жанровима, у дефиницију формуле би и њих требало укључити. Уз то, треба имати на уму отвореност, динамичност и помичност формуле коју Мирјана Детелић уочава, на пример, на почетку и на крају епске структуре (1996: 33 и 51), посебно зато што су динамичност и отвореност опште карактеристике традиције и нису својствене само епици. Овим се жели указати на чињеницу да укупна усмена традиција почива на својеврсној поетици формула. Важно је такође рећи да је: „Формула [...] средиште семантичке гравитације, на које се одлажу духовне вредности читавих епоха (Формула - это иентр семантической гравитации, на который оседают духовные иченности изельх эпох (Мальцев 1989: 87). И, сходно томе, поетика текста и поетика традиције садрже дубинска значења (текст активно комуницира с традицијом) која се сучељавају у формули (Мальцев 1989: 85). Или: „Формула - то је облик текста, и компонента његовог садржаја, и 'кретања' ка садржају, пут од 'облика' ка 'смислу'” (Формула - это и форма текста, и компонент его содержания, и способ „движения” к содержсанию, путь от „, формыл” к ,смыслуу" (Мальцев 1989: 54).

${ }^{22}$ Поменута формулативна конструкција није жанровски кодирана и јавља се, на пример, у фразеологизмима: Баба стариа звала уз врбопуи, а стараи јој се одазвао уз винобер. Или: Брига баби за удова стария; Видиш ли баба, кулу? - Не видим! - А видии ли стариа? - Назирем. И она је у вези прастарим веровањима у словенско божанство земље и плодности, баба је једна од њених хипостаза (Чајкановић 1994: 42-43).

${ }^{23}$ Деда (стараи) је лик који је у српској песничкој традицији, кодиран еротски и, сходно томе, у неким српским говорима поменуте речи означавају фалус (Златковић 2001: 24-25).
} 
Баба стариа у коло затвара,

Да не иде ноћу по седењке,

Да не ьуби [те] младе девојке.

Али стараи коло отворио,

На седењке ноћу отодио

И младе је девојке љубио.

(Слободанка Милојевић, Валевац)

Будући да је похотљивост стараца иначе распрострањени мотив одређеног сегмента српске традиције усменог певања ${ }^{24}$, њихово појављивање у оквиру седенћарких окупљања где су (као у Лужници) момци и девојке изводили шале, маскирајући се у старце (в. Ћирић 1977: 186) 25 , заједно с песмом која садржи нешто од тих детаља, исходи из прастарих веровања везаних за овај пар с првопредачким атрибутима ${ }^{26}$. И њихово понашање у песми (старац хоће, баба не да) уклапа се у систем митолошких представа везаних за њих. У стиховима се препознају трагови обредне смеховности и одговарајућег еротизма, који (у кризним тренуцима) у народној традицији има важну улогу (в. Зазыкин 2007: 5). Односно, шале се повезују с древним празницима аграрног и иницијацијског типа, који су у вези с преломним тренуцима у животу природе (завршетак вегетативног периода), друштва и човека (припрема за брак), који су обележени смрћу и васкрсењем, сменом и обнављањем (в. Bahtin 1978: 12-18), заклањајући старост и истрошеност хипертрофираном сексуалном жељом, што је овде случај - старац љуби девојке. А и хронотоп седенћарског окупљања маркира такву зону време-простора (измећу лета и зиме, ноћ, раскрсница итд.). И, сходно томе, седенће се (углавном) не одвијају у сигурности дома, већ изван заштићених зона, где престају да важе уобичајена правила друштвености ${ }^{27}$, којим кореспондира садржина песама, усклађујући се с дешавањима која се одвијају на седенћи.

${ }^{24}$ Види: Караџић 1974: бр. 79, 80, 81, 83, 84, 85. 86, 87, 88. 89, 89, 90, 91, 92.

${ }^{25}$ Такође су се момци преоблачили у женску одећу и девојке у мушку, у чему се огледа андрогиност карактеристична за регресију у првобитно стање стварања света, па сходно томе, и за припадајућу свадбену обредност (в. Иванов 1977: 46-64), чија је прва фаза нерашчлањеност (в. Bahtin 1978: 339-340).

${ }^{26}$ Баба је један од основних ликова календарске обредности код Срба и Словена - Кад се баба смеје, њен смех (као и Деметрин) изазива сијање сунца, односно плодност (Плотникова 2001: 11-12). И деда се у словенској митологији доводи се у везу с аналогним култовима (Седакова 2001: 148-151). А у вези с аналогним култом предака овај пар се везује и с чуварима дома (Иванов и Топоров 1965: 171 и 180).

${ }^{27} \mathrm{O}$ семантици ноћи види посебно: Братић 1993. 
За песму под бр. 3 у овој збирци Вукосава Милетић (Бучје) поменула је и да је извођена „на седењкама, кад дође стар момак, па млади момци не смеју од њега да приђу, да га отерају”. Она у целини гласи овако:

Иди, си, иди, дангубо,

Не губи ноћи бадава.

За тебе нема седењка,

За тебе нема девојка.

Црна ти земљь простирка,

Ведро ти небо завојка,

Шарена мачка девојка.

И ови стихови одговарају обичају да на седењкама учествују превасходно млади (да њима припада време раскалашности и весеља). Учесници зато и терају старијег, обраћајући му се грубим речима ( $u \partial u, c u, u d u)$ и ругајући му се, уједно нарушавајући уобичајене норме свакидашњег живота и смештајући старије чланове заједнице на друштвену маргину, у овом случају именовањем непожељног прелџију дангубом. Али то спорење узраста $^{28}$, могуће је, одговара и стварним играма преоблачења младих у старце и шалама које су са њима на седењкама извођене (в. Ћирић 1977: $176)^{29}$, о чему су говорили и наши информатори. Тако се показује да је овај смех, као и сваки празнични, усмерен на све и свакога, па и на саме учеснике у догађају (в. Bahtin 1978: 18) - у овом случају реч је о снижавању, спуштању на земљу непожељног учесника (или маскираног, а пожељног), у формулативно кодираном исказу: Црна ти замља простирка ${ }^{30}$, и на овај начин сједињавању с њом, као и с начелом апсорбовања и начелом рађања. И то је такође део прастарог концепта плодности (в. Bahtin 1978: 29). Овакву природу седенће потврђује и наставак песме: Ведро ти небо завојка / Шарена мачка, девојка (који људско измеће из окружења друштвености и доводи га у везу с природом и космичким силама (земљом, небом, а затим и животињама). И то представља друштвену регресију, која је карактеристична за тренутке промене у људским животима и у природи, какви се бележе седељкама (крај вегецијског периода и предбрачно стање). Уз то је сусрет старог и младог, животињског и људског,

${ }^{28}$ Овакве асоцијације на парна лица, спорења младости и старости, део су народних празничних форми повезаних са сменом и обнављањем. То су дијалози разнодобних сила и појава, односно дијалози два пола постања, почетка и краја (Bahtin 1978: 451-452).

${ }^{29}$ Игре, игрокази, преоблачења, маскирања, као и прерушавање у старце, обележја су обредне смеховности у календарским ритуалима и у свадби (в. Карановић 2007: 5-22; Карановић и Јокић 2011: 161-175), елементе којих садрже и окупљања на седенћи.

${ }^{30}$ Аналогно: Душек им је ирна земља... / Јорган им је ведро небо... (Караџић 1824: бр. 342; 1841: бр. 622). 
карактеристичан за премодерно поимање света и тела, које је могуће само у овако из свакодневице изметнутој, иделизованој комуникацији (в. Bahtin 1978: 428), ма колико да то нема везе с реалношћу, или управо због тога. И она овде постоји и показује се формулативним стихом: За тебе, мачка шарена. А све то и „игре стараца” уводи у контекст смеховне обредности. Исто тако, паралелизмима стихова и њиховим понављањима, алудурајући на природу седенће, на којој су дозвољена слободнија понашања младих (само у одређено време), кажу: За тебе нема седенка / За тебе нема девојка, што је такође формулативни исказ, који се јавља и у песми бр. 4 ове збирке и „гарантује” њихову традиционалност, имплицитно одређујући и пожељне учеснике. И овај вид понашања, који рефлектује песма, даље седељку утемељује у обред. У оквирима саме седељке, наиме, одвијају се паралелне активности - стварносна и представљчко-стварносна. Присуство паралелних светова не условљава само комични ефекат, већ садржај песме ситуира у смеховну културу (в. Карановић и Јокић 2009), отварајући могућности за смештање садржаја у шири контекст од самог окружења извођења. А и формулативност стихова песме, те одсуство личних имена, потврђује њену утемељеност у традицији. И зато су песме развијеније садржине, с неименованим и формулативно кодираним ликовима, чији су јунаци похотљиви старци, имале већу вероватноћу да преживе једно извођење, што показује и варијантни запис ове песме, који потиче са ширег регионалног терена (Грбић 1909: 284).

Једна дијалошка песмица, испевана у истом расположењу, забележена у Валевцу, затим, говори о промискуитетном старијем прелџији (бр. 2), у стиховима:

„А бре, чичо Костадине,

Колко жене имаш?" -

„Две у кревет, две под кревет

И две код комиију.”-

„А бре, чичо Костадине,

Колко деиу имаш?" -

„Две у ьуљку, две под љуљку,

А две јако мислим да се роде."

(Слободанка Милојевић)

И она садржином допуњава раскалашно расположење седењке. А како телесно, сексуалност, старост и младост, односно потенцијално обнављање у оваквим песмама има изворишта у обредној смеховности, у којој се смрт и страх од смрти превладавају хипертрофираном сексуалношћу, плодношћу и еротизмом (овде великим бројем жена и спрем- 
ношћу да се оне деле са комшијом, као и многобројном децом), у основи ове песме налази се кључ за разумевање једног сегмента традицијског певања, карактеристичног за обредно-смеховни однос према свету (в. Карановић и Јокић 2009), у оквиру којег су промискуитет и слободно понашање не само дозвољени већ и пожељни (о томе и Кајоа 1986: 33, $35,47-48)$, па макар само у песми. И овакви примери песничке традиције, како се показује, посебно се везују за оне групације које су своју биолошку функцију испуниле (старци), или оне које тек треба да је достигну, дакле оне старосне и социјалне категорије које се налазе изван тог искуства, што их, с тачке гледишта друштвености, уводи у маргиналне просторе и просторе обредне инверзије понашања.

За разлику од претходне, следећа песма, забележена такође у Валевцу, започиње свеченим, узвишеним тоном, инвокацијом божанства и најавом чуда на земљи, у римованим мелодичним стиховима:

Слезни, Боже, озгор са небеса,

Па да видиш на земьи чудеса!

И то се одмах завршава, својеврсним снижавањем, представљањем онога шта би Бог видео - ако би сишао на земљу:

Како жене посташе девојке,

На девојке преузеше момке.

(Слободанка Милојевић)

Све је ту у супротности с очекиваним - инверзија понашања учесница, по старости и социјалном статусу: девојке - жене, те враћање у позицију неудатих, али и бестидних. Тај изненадни семантички обрт очекиваних учесника и понашања, у координацији с римом (постаме девојке и преузеше момке), ствара комични ефекат, што је такође карактеристика смеховне димензије ритуала у којој се похотљивост пожељна.

У Равни је од Љубице Божић забележена песма у којој девојка императивном конструкцијом прво тражи да јој пси некога долају (бр. 4), стиховима:

Лајте га, пиета, лајте га,

Близо га до мен'долајте. -

А затим, кад тај неко (момак?) дође, обраћа му се погрдним речима, у стиховима:

Не седај близо до мене,

За тебе нема девојка, 
За тебе маца шарена,

У оне баште зелене,

Под оне руже румене,

Па пази да те не загребе,

Мачеће ране љутице.

Уводна ситуација песме аналогна је стихованим инвокацијама песама из Лужнице ${ }^{31}$, које потврђују постојање традицијске матрице овог исказа. Традицијском певању одговарају и девојчине речи упућене псима и односе се на момка: Близо га до мен' долајте, којег је тако и дозвала, а затим одгурнула: Не седај близо до мене / За тебе нема девојка, чему следи даље снижавање у шаљивом тону: За тебе маца шарена, што је аналогно стиху из песме ове збирке под бр. З. Завршетку песме пак претходи интерполација стиховима: У оне баште зелене / Под оне руже румене, изнова и неочекивано потврђујући матрицу традиције у пуном смислу (локус врта и ружа, с устаљеним епитетима), све до тренутка док се, хистериологијом одгађајући такође неочекивани крај, показује (подразумева) да је у врту мачка, од које девојка (одједном) стрепи и упозорава момка, речима: Па пази да те не загребе, алузивношћу исказа дозивајући дечју игру и својеврсну регресију ка њој. И на крају, страх, стварни или фингирани, да момак може страдати, пошто су: Мачеће ране љутице, што изазива својеврстан комични ефекат.

Збивање се, дакле, одвија на два плана - комбинацијом традицијских средстава изражавања и дистанцирањем од њих и еклатантан је пример мешања не само старијих и новијих изражајних средстава, већ и својеврсна демострација двосмислености исказа, у неколико каламбурних ситуација, својствених смеховном поимању света.

${ }^{31}$ Поменуте седенћарске песме из Лужнице гласе овако:

Пиетата знају кога лају,

Ако је старо, лајте га,

Ако је младо, дајте га!

Јанка пиета не лајте,

Нело га овамо дајте!

(Ћирић 1977: 178)

Наклала Јанка седнећу,

Наклала огағ големи,

Наклала, момии окала -

O пиета, пиета, наши не лајте,

Пиетата Перу знају, па знају,

Кад иде на седенћу, она га не лају!

(Ћирић 1977: 187) 
И на крају су записи две песме из Кожеља, за које је Анка Цветковић рекла да су се „певале на седенћу” и да их је „научила од бабе” (бр. 18 и бр. 15), што је сведочанство о њиховом тада још увек непосредном, мада спорадичном, преношењу с генерације на генерацију. Оне у целини гласе овако:

Звездо ле, звездице ле,

Огреј мене на двора,

Да ја видим ито љубим,

Дал'је старо, да л’младо.

И:

Наран' ђуле, не падај на мене

На мене су до два, до три јада.

Едан јада, ито ме младу просе,

Други јада, за старог ме носе.

Волим с младо на камен спавати

Нег са старо у мека душека.

Волим с младо камење бројити,

Нег са старо жутици дукати.

И ове песме су по својој структури, садржини и основном тону другачије од оних које су до сада коментарисане.

Обе те песме граде се по аналогној композиционој матрици, императивном конструкцијом, јунак (девојка) обраћа се некоме (нечему), што условљава оријентацију према примаоцу од којег се нешто тражи или очекује, што је један од примарних облика комуникације (в. Jakobson 19: 292) и „гарант” архаичности композиционог поступка. У обе песме, затим, у фиктивну релацију доводе се људска бића и природни елементи (звезда, ружа), што је такође прастари вид општења, који се остварује у озбиљном тону, за разлику од осталих песама ове збирчице. Јер оне, и кад се граде на исти начин (Иди си, иди дангубо или Лајте га, пцета, лајте га), своје песничке реализације остварују у комичном тону, на матрици каламбура, изненадним и неочекиваним обртима. И зато ове две седенћарске песме у записма из Тимока чине специфичну категорију. Садржином оне се такође везују за омиљене мотиве српске усмене лирике: млад вољен и стар невољен војно, односно девојка неће за старца (в. Krstić 1984: 245). И стога се може учинити да су лабавије везане за радње и поступке на седенћи, што није тачно, будући да су обе тематски заокупљене припремом за брак (иницијацијске су природе). То је посебно евидентно у другом примеру, који је, у неколико варијаната, забележен и као сватовска песма 
(Ястребов 1889: 438-439; Божиновић, Станковић и др. 1962: 65; Ђорђевић и Златановић 1990: бр. 188).

У првом примеру наратор и вршилац радње (девојка) обраћа се звезди формулативном наредбом, односно молбом ${ }^{32}$, хипокористички јој се додворавајући (звездо ле, звездице), молећи је да осветли простор (двор), да „огреје”. У другом делу песме, демистификујући своје разлоге стварном ситуацијом чији је актер она сама, стиховима: Да ја видим шта љубим / Да л'је старо, да л'младо, отвара се простор еротској димензији контекста у којем је песма извођена и она се овом димензијом уклапа у атмосферу седенће. Регионална развијенија варијанта, с мелодијским записом, забележена у новије време у Добричу (Шорак 2017: 223). И својим уводним стиховима она, заједно с нашим записом, потврђује живот ове песме у сећању појединачних припадника заједнице крајем 20. и почетком овог века.

Друга песма се отвара девојачком молбом ружи (ђулу) да се не круни и не пада на њу. Њен исказ, фокусиран на раскид контакта с ружом, иде у супротном смеру од претходне (веза са звездом), али је такође кодиран формулативно, будући да се овај цвет редовно доводи у везу с иницијацијом, а раскид са њиме везан је с нежељеним браком или његовим завршетком (в. Карановић 2010: 275-277) и редовно представља уводне стихове песама с овим мотивом на српском простору ${ }^{33}$. Образлажући разлоге свог стања и описујући интензитет бола, девојка наставља: Едан јада, што ме младу просе, / Други јада, за старог ме носе. Понављањем за њу кључних речи у паралелизмима нежељених поступака (просе, носе), даље (формулативним исказима) интензивира осећање бола и градацијски га подиже. О актерима зла, што је просе младу и што је дају старом, девојка не говори, већ их обезличује, множинским обликом трећег лица трајних глаголских речи (изостављајући чак и заменичке конструкције), имплицирајући не само бројност и безочност актера већ и трајност зла

${ }^{32}$ Види нпр. везу уводних ситхова наше песме са записом такође седенћарске песме који у целини гласи овако:

Месечино, дафино,

Сини, мини до двора!

(Манојловић 1953: бр. 88)

${ }^{33}$ На пример: Не рон' ђуле, не падај по мене / Мен'је мајћа младу оженила, / Оженила, добро намерила (Николић: 1910: 359-360, исто Манојловић, 1953: бр. 223 и Живковић 1998: 58-59), или: Не рон ђуле, / Не падај на мене / На мене су бриђе надолеле / Једна брига што се не удадо, / Друга брига што си војно немам" (Јоцић 1979: бр. 91). Такође: Булум иутит, на девојку капит, / Девојка му ђулуму говорит: / „А ђулуме, порано иветение / Што ти иутиш, а на мене капеш / Ако иутии, на мене не капи / Ја си има големи дертови / Млад ме питат, за старо ме дават" (Яастребов 1889: 438-439). 
које јој се наноси. Песма се завршава формулативним исказима типа: волим с младо, нег са старо, аналогно многобројним варијантним записима ове песме код нас, које је Вук Караџић публиковао још у Рјечнику ([1818] 1966. и 1852) уз одредницу недраги.

Истраживање грађе и одговарајуће литературе везане за седенћу у селима око Белог Тимока, као и увид у аналогна окупљања на српском духовном и демографском простору (прела/сијела) показало је да су она некада имала обредни карактер, што потврђује време-простор њиховог одвијања. Седенће су започињале о јесењим празницима који маркирају промене у природи и односе се на крај вегетативног периода, а у југоисточној Србији одвијале су се ноћу, поред ватре, у односу на људску заједницу у граничним просторима - на раскрсницама, на сред села, под записом итд. Учесници су били доминантно млади (девојке и момци), насупрот старима, који нису били добродошли, што представља својеврсну иницијацијску изолацију биолошки спремних за брак. Њихово понашање - представљачки елементи, маскирање и преоблачење, оргијазам, магија, свирка, различити наративи и ненаративни искази (песме, шале, приче, игре, разбрајања, загонетања) - у инверзији су с правилима свакодневице. И све то одговара смеховној димензији ритуала, која је на седенћи доминантна, али не и искључива. Друга страна седенћарских окупљања пак огледа се у супротстављеној озбиљној димензији седенће, кад су певане и песме озбиљне садржине.

Седенћарске песме, забележене у селима око Белог Тимока пак прате, коментаришу и објашњавају поменуте поступке и акције, односно уклапају се у одговарајуће ситуације оваквих окупљања, чији су део и биле. И оне су у основи пригодног карактера. Према прилици у којој су извођене, као и по садржинским асоцијацијама, ове песме блиске су посленичким. Основном емоцијом пак као и остале песме певане на сличним окупљањима, везују се за љубавне. То су углавном песмице тренутне емоције и импровизације. И оне, без обзира на постојање неочекиваних рима и урбану лексику, којом се удаљавају од матрице традицијског певања, донекле остају у старим калупима. Управо постојање старог и њему непримереног новог (паралелне поетичке стварности) у песмама резултира неочекиваним обртима, који својом комичношћу враћају стихове прастарим упориштима. Комични ефекти постижу се и хипертрофираним еротизмом и похотљивошћу, посебно стараца који су своју биолошку функцију испунили, што их, с тачке гледишта друштвености, уводи у маргиналне просторе, односно просторе обредне инверзије понашања, које их уклапа у систем митолошких представа из култа плодности, показујући и одговарајуће трагове обредне 
смеховности. Тако се у основи ових песама налази кључ за разумевање сегмента традицијског певања карактеристичног за обредно-смеховни однос према свету у српској култури у целини. Наравно, на седенћу су извођене и песме које припадају старијем слоју певања које својом формулативношћу мотивски ширим опсегом метричко-ритмичком структуром и сл. одударају, али су тематски такође везане за обичај ноћног окупљања. И оне одговарају озбиљном сегменту пригоде ове врсте, осветљавајући седенћу у пуноћи њене обредности. И то се овде очитује, без обзира на фрагментарност расположиве грађе.

\section{ЛИТЕРАТУРА}

Бахтин 1978: M. Bahtin, Stvaralaštvo Fransoa Rablea i narodna kultura srednjega veka i renesanse, Nolit: Beograd.

Божиновић, Станковић и др. 1962: С. Божиновић, М. Станковић и др., „Што ли Тимок мутан тече”, Развитак, бр. 4-5: 63-67.

Бошковић 1879: С. Бошковић, Бачванске песме, Нови Сад: Српска народна задружна штампарија.

Братић 1993: D. Bratić, Glugo doba, predstave o noći u narodnoj religiji Srba, Beograd: Prosveta.

Грбић 1909: С. М. Грбић, Српски народни обичаји у срезу бољевачком, Српски етнографски зборник, XIV, Београд: Државна штампарија Краљевине Србије.

Детелић 1996: М. Детелић Урок и невеста, поетика епске формуле, Београд: САНУ и Универзитет у Крагујевцу.

Ђорђевић и Златановић 1990: Д. Ђорђевић и М. Златановић, Народне песме из Лесковачке области, Београд: САНУ.

Живковић 1998: Н. Живковић, Гора бршљанова, народне песме пиротског краја. Пирот: Музеј Понишавља.

Зазыкин 2007: В. И. Зазыкин, О природе смеха, Москва: „Ладомир”.

Златковић 2001: Д. Златковић, Срамотно и погано у пиротском говору. Београд, София: ИП „Еcolibri,” Музеј Понишавља, „Диос”.

Иванов 1977: В. В. Иванов, „К семиотической теории карнавала как инверсии двоичных противпоставлений”, у: Труды по знаковым системом, VIII. Тарту: Ülikool. 45-64

Иванов и Топоров 1965: В. В. Иванов и В. В. Топоров, Славянские языковые моделирующие семиотические систем, Москва: Наука.

Ястребов 1889: И. С. Ястребов, Обычаи и песни туреиких сербов, Снактпетербургъ: Типография В. С. Балашева. 
Јоцић 1979: Љ. Јоцић, Бул девојче, лирске народне песме из белопаланачког краја, прир. Ж. Јоцић и др., Ниш: Градина.

Kajoa 1986: R. Kajoa, „Teorija praznika”, Kultura: časopis za teoriju $i$ sociologiju kulture i kulturnu politiku, 73-75, Beograd 32-60.

Карановић 2007: 3. Карановић, „Обредни жанрови и књижевне врсте у покладним ритуалима", у: Синхронијско и дијахронијско изучавағе врста у српској књижевности, vol. 1, ур. 3. Карановић, Нови Сад: Филозофски факултет Дневник: 5-22.

Карановић и Јокић 2009: 3. Карановић и Ј. Јокић, Смеховно и еротско у српској народној култури и поезији. Нови Сад: Филозофски факултет.

Карановић 2010: 3. Карановић, „Ружа у српској народној традицији и народној поезији”, у: Небеска невеста. Београд: Друштво за српски језик и књижевност Србије: 261-288.

Карановић и Јокић 2011: 3. Карановић и Ј. Јокић, „Обредни смех у песмама календарског циклуса", у: Годишњак Филозофског факултета у Новом Саду, XXXVI, Нови Сад, 161-175.

Караџић [1815] 1965: В. Ст. Караџић, Народна србска пјеснарица (1815), у Сабрана дела Вука Караџића, књ. прва. прир. В. Недић: Београд: Просвета.

Караџић 1818: В. Ст. Караџић, Српски рјечник истумачен њемачким и латинскијем ријечима, Беч: Штампарија Јерменског манастира.

Караџић 1824: В. Ст. Караџић, Народне сриске пјесме. Къ. 1, у којој су различне женске пјесме, скупио и и на свијет издао Вук Стеф. Караџић, у Липисци у штампарији Брејткопфа и Ертла.

Караџић 1841: В. Ст. Караџић Српске народне пјесме, I, Беч: Штампарија јерменског манастира.

Караџић 1852: В. Ст. Караџић, Српски рјечник истумачен њемачким и латинскијем ријечима. У Бечу: Штампарија Јерменскога намастира.

Караџић 1974: В. Ст. Караџић, Српске народне пјесме из необјављених рукописа Вука Стеф. Караиића, Книга пета, Особите пјесме и поскочище, за штампу приредили Живомир Младеновић и Владан Недић, Београд: САНУ.

Крстић 1984: В. Krstić, Indeks motiva narodnih pesama balkanskih Slovena, uredio Ilija Nikolić. Beograd: Srpska Akademija nauka.

Лорд 1990: A. B. Lord, Pеvač priča I i II, prev. S. Glišić, Beograd: Idea.

Мальцев 1989: Г. И. Мальцев, Традиционалньие формульы русской народной необредовой лирики. Наука: Ленинград.

Манојловић 1953: К. П. Манојловић, Народне мелодије из источне Србије, Београд: САНУ. 
Недељковић 1990: М. Недељаковић, „Преображење”, у: Годишґи обичаји у Срба: Београд: „Вук Караџић”: 188-189.

Николић 1910: В. М. Николић, „Етнолошка грађа и расправе: из Лужнице и Нишаве”, у: Српски етнографски зборник. књ. 9, Београд: Српска краљевска академија: 359- 360.

Петровић 1998: П. Ж. Петровић, „Преображење”, у: Српски митолошки речник, Београд: Етнографски институт САНУ, Интерпринт.

Плотникова 2001: А. А. Плотникова, „Баба Марта”, Словенска митологија, ред. С. Толстој и Љ. Раденковић, Београд: Zepter book world: 11-12.

Проп 1984: В. Ја. Проп, Проблеми комике и смеха, Нови Сад: Дневник.

Раденковић, Бранимир: Село Стрелац, монографија https://www. monografija.rs/monografija/kulturna-bastina/pesme/ 22. 08. 2016.

Ризнић 1894: М. Ст. Ризнић, „Седељке, један народни обичај из Источне Србије”, Браство: 95-135.

Самарџија 2010: С. Самарџија, „Усмени жанр и јунак у семантичкој активности (уводне напомене)", у: Ликови усмене књижевности, ур. Снежана Самарџија, Београд: Институт за књижевност и уместност: 7-27.

Седакова 2001: И. А. Седакова: „Дедови” у: Словенска митологија, ред. С. Толстој и Љ. Раденковић. Београд: Zepter book world.

Станковић [1906] 1951: Ж. Станковић, Народне песме у Крајини (предато Академији 1906), Београд: САНУ.

Станојевић 1929а: М. Станојевић, „Обичаји и веровања у Тимоку”, Гласник етнографског музеја, IV, Београд: 42-54.

Станојевић 1929б: М. Станојевић, „Свадбени обичаји у Тимоку”, Зборник прилога за познавање Тимочке крајине, 1, Зајечар: 23-77.

Чајкановић 1994: В. Чајкановић, Стара српска религија и митологија, Сабрана дела 5, прир. Војислав Ђурић. Београд: СКЗ, БИГЗ, Просвета, Партенон.

Ћирић 1977: Д. Ћирић, Седенћа у Лужници, Гласник етнографског музеја у Београду. књ. 41: 175-194.

Шорак 2013: М. Шорак, „Седењка и седењкарске песме у Добричу”, у: Гласник етногрфског музеја, 77: 207-225. 
Zoja S. Karanović

\author{
HUMOROUS AND EROTIC ELEMENTS IN SERBIAN FOLK SONGS \\ SUNG IN THE PAST AT AUTUMNAL NIGHT GATHERINGS (SEDENĆA) - \\ THE FIELDWORK COLLECTION FROM THE TERRAIN \\ AROUND THE RIVER BELI TIMOK
}

\begin{abstract}
Summary
The subject of this paper is recording of Serbian folk songs that were performed in the past at the autumnal night youth gatherings (sedenća). They were collected in the villages around the river Beli Timok (southeastern Serbia), in 1997 and 1998, from elderly llocal peasant women who as young girls gathered in the mentioned sessions.

Sedenća used to began on autumn Hristian holidays (like Feast of the Transfiguration) marking changes in nature and refering to the end of the vegetative period too. The participants were predominantly young people, opposed to the elderly who were not welcomed. Sedenća took place during the night, outdoors, by the fire - in spatial-time boundaries of the community. And the freely behavior of participants - masking and disguise, orgy, with various narratives and expressions (songs, jokes, stories, games, reasoning, riddles) - were in inversion with the rules of everyday life. That way sedenća gathering refers to initiation isolation of those who are biologically ready for marriage. And all this corresponds to the carnivalization of the ritual in its actions and verbalizations (songs) which are the subject of this paper. All of this indicates that colected verses are based on the corresponding rituals, what I am trying to prove.
\end{abstract}

Keywords: villages around river Beli Timok, field records, Serbian oral tradition, lyrical folk song, ritual laughter

\title{
ПРИЛОГ
}

\section{Седенћарске песме}

Баба старца у коло затвара,

Да не иде ноћу по седењке, Да не љуби (те) младе девојке.

Али старац коло отворио,

На седењке ноћу отодио

И младе је девојке љубио.

(Слободанка Милојевић, Валевац) 
„А бре, чичо Костадине,

Колко жене имаш?" -

„Две у кревет, две под кревет

И две код комшију." -

„А бре, чичо Костадине,

Кол'ко децу имаш?" -

„Две у љуљку, две под љуљку,

А две јако мислим да се роде.”

(Слободанка Милојевић, Валевац)

Иди си, иди дангубо,

Не губи ноћи бадава.

За тебе нема седењка,

За тебе нема девојка.

Црна ти земља простирка,

Ведро ти небо завојка,

Шарена мачка девојка.

(Вукосава Милетић, Бучје, 17. 4. 1998, на седењкама, кад дође стар момак, па млади момци не смеју од њега да приђу, да га отерају)

Лајте га, пцета, лајте га, Близо га до мен' долајте. Не седај близо до мене, За тебе нема девојка. За тебе маца шарена У оне баште зелене, Под оне руже румене, Па пази да те не загребе, Мачеће ране љутице. (љубица Божић, Равна)

Бела лампа, зелен гас, Ајте, момци, сви код нас. (Слободанка Милојевић, Валевац) 
Иде гара, свитка му цигара, Иде луче, залаја га куче.

(Вукосава Милетић, Бучје)

Синоћ ми је долазио Миле, Донео ми три кутије фине. $\mathrm{Y}$ једну је пудер и помада, А у другу шећер, чоколада, А у трећу, девојчица млада. (Каравилка Радивојевић, Јелашница)

Дор седе, седе седенћа, Па кад се вану растура, Кој с брата, кој с побратима (Име девојке) нема с куга, (Име момка) јо ручак заруча, Да иде (име девојке) да руча. (Љубица Божић, Равна)

Старо сено развучено (име девојке) Узни вилу, прибери га (име момка).

(Слободанка Милошевић, Дебелица, припевала се девојка момку, као да му се препоручује)

Густо сито, чисте трице (име девојке)

Од кога су те модрице (име момка)

(Слободанка Милојевић, Дебелица)

Седенћа седе што седе,

Па кад се поче разоди

Кој с брата, кој с побратима, 
А (име девојке којој се припевља) нема с кога.

Да дојде (име момка) да си ју кући одведе.

(М. Тодоровић, Корито)

12

Пловка ми пловеше

Уз Дунав, низ Дунав.

Није ми пловка,

Него је (име девојке).

Кршила, ломила,

С (име момка) се љубила.

(На седењке, припевка, казала Здравка Јеленковић, Дреновац)

Ала волем, па волем,

Сас два вола да орем,

А сас коња да угарим,

Цуру да преварим.

(Милица Петковић, Врбица)

Иде Миле навише,

С лакуване кајише.

А чарапе навезене,

Дај га, Боже, мене.

(Милица Петковић, Врбица)

Звездо ле, звездице ле,

Огреј мене на двора,

Да ја видим што љубим,

Да л’ је старо, да л’ младо.

(Анка Цветковић, Кожељ, седенћарска и од бабе) 
Слезни, Боже, озгор са небеса, Па да видиш на земљу чудеса Како жене посташе девојке, На девојке преузеше момке. (Слободанка Милојевић, Валевац)

Ој девојко, Јуле,

Ој девојко, Јуле, буле,

Бриго материна.

Све се бринеш, Јуле,

Све се бринеш, Јуле, буле,

Не мож’ да се удаш.

Удаћеш се, Јуле,

Удаћеш се, Јуле, буле

И покајаћеш се.

Код мајку си, Јуле,

Код мајку си, Јуле, буле,

Код мајку си бела и румена,

А код војно, Јуле,

А код војно, Јуле буле,

Жута пребледела. -

Војно тражи, Јуле,

Војно тражи, Јуле, буле,

Војно тражи ручак и вечеру.

По вечеру, Јуле,

По вечеру, Јуле, буле,

По вечеру, тебе испрошену.

(Слободанка Милојевић, Валевац)

Наран' ђуле, не падај на мене.

На мене су до два, до три јада.

Едан јада, што ме младу просе, Други јада, за старог ме носе.

Волим с младо на камен спавати, Нег са старо у мека душека.

Волим с младо камење бројити, Нег са старо жутици дукати.

(Анка Цветковић, Кожељ, на седењку, научила од бабе) 